\title{
Sources of Technical Inefficiency of Smallholder Cow Milk Producers in Yabelo District of Oromia Region, Ethiopia
}

\author{
Belay Biru (Msc.) \\ Yabello Pastoral and Dry Land Agriculture Research Center, Yabello, Ethiopia \\ Degye Goshu $(\mathrm{PhD})$ and Bosena Tegenge $(\mathrm{PhD})$ \\ Department of Agricultural Economics, Haramaya University
}

\begin{abstract}
This study measures the level of technical efficiency of smallholder cow milk producers using stochastic production approach of Cobb-Douglas production form and identified the possible cause for inefficiency in cow milk production using Tobit regression model. The data collected from 177 sample household randomly selected from pastoral and agropastoral Kebeles of Yabelo district. The result indicated the mean technical efficiency of cow milk producers of $71.42 \%$. This means if producers are producing in fully efficient way, they can save on average $28.56 \%$ of their current input to produce their current output or increase their current milk output by $28.56 \%$ without additional inputs requirement. The gamma parameter, $\gamma$, was found to be 0.70 showing $70 \%$ of the deviation of actual output from potential output was due to technical inefficiency. Among the five inputs used, milk output was positively and significantly the function of labor, grazing land, and hay forage. The result of Tobit regression model shows that family size, size of livestock holding, extension contact, distance to veterinary clinic, distance to water positively and significantly contributed to inefficiency while age and education level of household head negatively and significantly affecting inefficiency of milk producers. Evidently intervention on access to water source, veterinary clinic, education, family planning and productivity oriented livestock holding will improve technical efficiency of cow milk producer of the study area.
\end{abstract}

Keywords: Technical efficiency, stochastic production approach, Tobit regression, Yabello district.

DOI: $10.7176 / \mathrm{FSQM} / 99-01$

Publication date:July $31^{\text {st }} 2020$

\section{INTRODUCTION}

In Ethiopia, pastoralists and agro-pastoralists use $60 \%$ of the country's land area (MoARD, 2005). Pastoralist and agro-pastoralist are based mainly on livestock and livestock products for their livelihood. The dairy products in dry areas like Borana known to contribute significantly to the household food and income needs among poor households (Dejene and Tamiru, 2015; Kebede and Alonso (2018)

There is increasing market demand milk due to Ethio-Kenya border trade and high liquid milk consumption behavior at Borena area with increasing population. Fresh milk is traded along the road Addis Abeba (finfine) to Moyale at available rural market. Despite relatively emerging market demand for milk from this area, productivity of livestock particularly dairy is decreasing over time (Tache and Oba, 2010). Hence, increasing dairy production and productivity has significant role in benefiting smallholder rural dairy producers particularly in the dry areas of the country representing $65 \%$ of domestic milk output (FAO, 2011).

Agricultural outputs can be increased by developing and adopting new technologies, by decreasing cost of inputs or by improving management practices. On the other hand, low diffusion and adoption of new technology at farm level is among the problem facing dairy production in the country (Azage et al., 2013). Only new adopted technology itself even could not result in increased agriculture output. There is a need for the integration of modern technologies with improved level of efficiency.

Some development initiatives in the pastoral areas are dedicated to promote the various non-technical approaches to change organizational and behavioral features of pastoral societies rather than productivity (Oxfam, 2014). Enhancing production and productivity to sustain the growing demand for cow milk, understanding technical efficiency of milk producers found in this area is vital. But there is scanty empirical evidence on technical efficiency of milk producers in Ethiopia particularly in Borana Zone. Thus, this study intended to contribute to technical efficiency literature of milk producers in quantifying the level of technical efficiency for cow milk producers of Yabelo district in Borana zone.

\section{MATERIALS AND METHODS}

\subsection{Description of the Study Area}

Yabello is the capital town of the Borana zone. Yabello found at 567km south of Ababa (Finfine) has a total of 13 peasant associations and two urban dweller associations (El-way and Haro Bake). The altitude of this Woreda ranges from 350 to 2200 meters above sea level. There are no rivers and streams in Yabello or rivers crossing it except traditional wells and ponds. Obda highland and El-waya lowland are the major features in the district. 
The mean annual temperature ranges from $12^{\circ} \mathrm{c}$ to $24^{\circ} \mathrm{c}$ and a prominent feature of the ecosystem is the erratic and variable nature of rainfall, with most areas receiving $238 \mathrm{~mm}$ and $989 \mathrm{~mm}$ annually, with a high coefficient of variability from $18 \%$ to $69 \%$. The total rural population of the district was 63,648 out of which 36,382 were men and 27,266 were female. The total households of rural peasant associations of the district were 10048 out of which 7880 were male and 2168 were female.

The district has bimodal rainfall pattern. The main rainy season extends from March to May whereas the short rainy season lasts from October to November followed by the long dry season. The short rains are unreliable. Variable rainfall results in greater variability in forage productivity. Seasonal distribution of rainfall is more important than the annual total rainfall in influencing forage production from rangelands. During the years of high rainfall, surplus forage is being produced and vice versa. As a result livestock productivity and production losses are expected during the years of below average rainfall (Cossins and Upton(1988). According to the Woreda Pastoral Development Office (2015; unpublished), the district's total livestock population is estimated to be 637,314 out of which cattle 265897, goats 222,779, sheep 97,011, horses 106, mule 833, donkeys 6646 and camels 44042.

\subsection{Sampling technique and sample size}

According to data from pastoral development office Yabelo district was classified under agro-pastoral district of Borana zone. However, Peasant associations classified into two homogeneous groups, namely agro-pastoral and pastoral. Households from each stratum as well as from each kebele were randomly selected. The sample size from each category and each Peasant association were based on the proportion sample allocation formula given as $n_{i}=\frac{n N_{i}}{N}$ ( Pandey And Verma, 2008). According to data from Pastoral development office, about 2775 households were under pastoral while 7273 households in agro pastoral peasant association. $n=n_{i=} \frac{n N_{i}}{N}+\frac{n N_{j}}{N}$ Where, $N_{i}$ and $N_{j}$ number of pastoral and agropastoral households respectively. This study was based on 177 households selected from the district.

\section{Methods of Data Analysis}

\subsection{Descriptive statistics}

This method of data analysis goes to the use of ratios, percentages, means, range, and standard deviation employed in examining and describing farm household, demographic and socio economic characteristics, production and resource use allocation in cow milk production.

\subsection{Econometric Model Specification}

First stochastic production function was used to estimate the technical inefficiencies of cow milk producer in the study area. Second tobit regression function was used to estimate the source of technical inefficiency specified as:

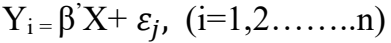

Where, $\varepsilon_{j}=v_{i}-u_{i}, y_{i}=$ output of farmer $\mathrm{i}, x_{i}=(\mathrm{k}+1)$ row vector whose first element is 1 and remaining ' $\mathrm{x}$ ' elements are ' $\mathrm{k}$ ' input quantities used by $\mathrm{i}^{\mathrm{t}}, \beta=\left(\beta_{o}, \beta_{j} \ldots \ldots \ldots \beta_{k}\right)$, is a $(\mathrm{k}+1)$ column vector of unknown parameters to be estimated. $\mathrm{Y}_{\mathrm{i}}$ is milk output in liters of milk produced by $i^{\text {th }}$ household, $X_{1}$ is grazing land available to the $\mathrm{i}^{\text {th }}$ household; $X_{2}$ is amount of crop residue of household from own production $(\mathrm{Kg}) ; X_{3}$ amount of forage feed supplied for dairy cows of the household per year in $\mathrm{Kg}$; and $X_{4}$ amount of labor (family and hired labor) per household (expressed in equivalent man-days). $\beta_{0}$ is the level of milk output from cows without any inputs and the other $\beta_{i}$ 's constitutes a vector of parameters to be estimated (they are the partial elasticity coefficients of the production function). $v_{i}$ is a symmetric error term, independently and identically distributed normal random variables with zero means and variances $\sigma^{2}$, i.e. $v_{i} \sim$ iid $\mathrm{N}\left(0, \sigma_{\mathrm{v}}^{2}\right)$, accounting for the deviation from the frontier because of factors which are beyond the control of the farmer (such as variation in weather, measurement error and other statistical noise), and $u_{i}$, is a one sided error term accounting for the deviation because of inefficiency effects.

Tobit model was employed to identify the determinate factors that affect the technical inefficiency in cattle milk production.

$Y_{i}^{*}=\sum \beta_{i} x_{i}+v_{i}$

$Y_{i}^{*}=\left\{Y_{\mathrm{i}}\right\}$ if $\mathrm{Y}_{\mathrm{i}}>0, Y_{i}^{*}=0$ if $\mathrm{Y}_{\mathrm{i}} \leq 0$,

$Y_{i}=1-\beta_{O}+\beta_{i} x_{i}+u_{i}$

Where, $x_{i}$ constitutes proposed inefficiency variables; age of household, education level, family size, distance to market, distance to veterinary clinics, distance to water source, family land size, total livestock unit excluding cows, extension contact, credit use, training, non/off farm income, and farming system. $Y_{i}$ Technical inefficiency is the latent dependent variable, $\mathrm{i}=1$ to $\mathrm{n}$ independent variables, $\mathrm{u}_{\mathrm{i}}=$ error term 


\section{RESULTS AND DISCUSSION}

\subsection{Descriptive statics of selected variables}

From the total respondent of the sample survey $80.80 \%$ were illiterate while $19.20 \%$ were literate. From the women involved in the survey only $6.67 \%$ of them were educated while $93.33 \%$ women were illiterate. Among all the educated respondents female shared about $11.67 \%$ only.

Table1. Marital status and sex of sample households

\begin{tabular}{|l|r|r|r|r|r|r|r|r|}
\hline \multirow{2}{*}{ Variables } & \multicolumn{9}{|c|}{ Mean values } \\
\cline { 2 - 10 } & pastoral & \multicolumn{1}{|c|}{ agropastoral } & \multicolumn{1}{c|}{ both } & \multicolumn{1}{c|}{ t-ratio } & \multicolumn{1}{c|}{ male } & \multicolumn{1}{c|}{ female } & \multicolumn{1}{c|}{ both } & t-ration \\
\hline Age & 43.97 & 41.09 & 41.70 & 1.02 & 42.30 & 40.50 & 41.70 & 0.75 \\
\hline Education/year & 0.98 & 0.92 & 0.94 & 0.70 & 1.23 & 0.38 & 0.94 & 0.57 \\
\hline
\end{tabular}

Source: own survey result (2018)

There was significant difference between male and female households in their education level at 5\% significance level.

Table 2. Summary statistics of input and output

\begin{tabular}{|l|c|r|r|r|r|}
\hline \multirow{2}{*}{ Variable } & \multirow{2}{*}{ Units } & \multicolumn{4}{|c|}{ Mean value } \\
\cline { 3 - 6 } & & Agro pastoral & \multicolumn{1}{c|}{ Pastoral } & \multicolumn{1}{c|}{ Both } & \multicolumn{1}{c|}{ t-ratio } \\
\hline Milk yield/year & Littre & 375.03 & 355.75 & 365.51 & 0.62 \\
\hline Labor/year & Man-day & 474.93 & 464.09 & 468.80 & 0.33 \\
\hline Grazing land/year & Hectare & 6.92 & 9.43 & 8.34 & 12.93 \\
\hline Hay Forage/year & $\mathrm{Kg}$ & 269.15 & 260.00 & 264.00 & 0.26 \\
\hline Crop residue/year & $\mathrm{Kg}$ & 684.27 & 541.27 & 603.50 & 1.81 \\
\hline
\end{tabular}

Source: Own survey result (2018)

\subsection{Econometric Analysis}

This paper follows a two-step estimation model. The first step involves the specification and estimation of the stochastic frontier production function and the prediction of the Technical Efficiency in the Smallholder cow milk Production. The second step involves the specification of a regression model for the predicted technical inefficiency effects.

\subsubsection{Estimation of stochastic production function}

Table 1. ML Estimates for SFA parameters and for CD model

\begin{tabular}{|l|l|l|l|c|l|}
\hline Variables & Coefficient & Std. Error & Diagnostic statics & Value & Std. Error \\
\hline Ln of labor & $0.62 * * *$ & 0.071 & $\lambda=\sigma_{\mathrm{u}} \sigma_{\mathrm{v}}$ & 1.510 & 0.154 \\
\hline Ln of grazing land & $0.46^{* * *}$ & 0.135 & $\sigma^{2}$ & $0.314 * * *$ & 0.074 \\
\hline Ln of hay forage & $0.02 * * *$ & 0.005 & $\gamma=\lambda^{2} /\left(1+\lambda^{2}\right)$ & $0.700^{* * *}$ & \\
\hline Ln of crop residue & 0.01 & 0.010 & Log likelihood & -95.64 & \\
\hline Constant & $1.68 * * *$ & 0.510 & & & \\
\hline
\end{tabular}

Significance codes: $1 \% * * * 0.05 \% * * 10 \% *$ significance level

Form the above input output function, all four inputs for milk production showed the expected positive sign to milk production. Among four inputs assumed as the function of cow milk production grazing land, labor inputs and forage turned to contribute in milk production at $1 \%$ significant level. The $\gamma$ value show that about $70 \%$ variation in milk output from frontier production is due to inefficiency problems of milk producers.

There is a wide variation of actual output from frontier output where about $70 \%(\gamma=0.70)$ of this deviation is due to technical efficiency problems (inefficiency). The range land productivity also indeed depending on rainfall that was spatial and erratic that what households could not manage or out of control. Even though government paid attention to disease and other institutional problems that affect pastoral areas, the spatial and erratic rainfall that in turn directly influence range land productivity is the most unpredictable. Thus, according to this result about $30 \%$ from frontier output might account to such pastoral areas environment. The mean technical efficiency of milk producers was found to be $71.42 \%$ with minimum $36.46 \%$ and maximum $90.13 \%$. There were no milk producers that approached to frontier output. Thus, there can be possible to increase much milk production through improvement in technical efficiency. In this result case, through technical efficiency improvement, producers on average could increase milk output/cow by $28.6 \%$ of what they are producing without requiring additional input with existing technology.

The distribution of the technical efficiency scores showed about $39.54 \%$ of sample respondent had less than mean technical efficiency score while the rest $(60.45 \%$ of the respondent hade greater than mean technical efficiency score). About $27.11 \%$ of the total household sample had greater than $80 \%$ technical efficiency score. This states that about $72.89 \%$ of sample respondent technical efficiency would be increased at least by $20 \%$. 


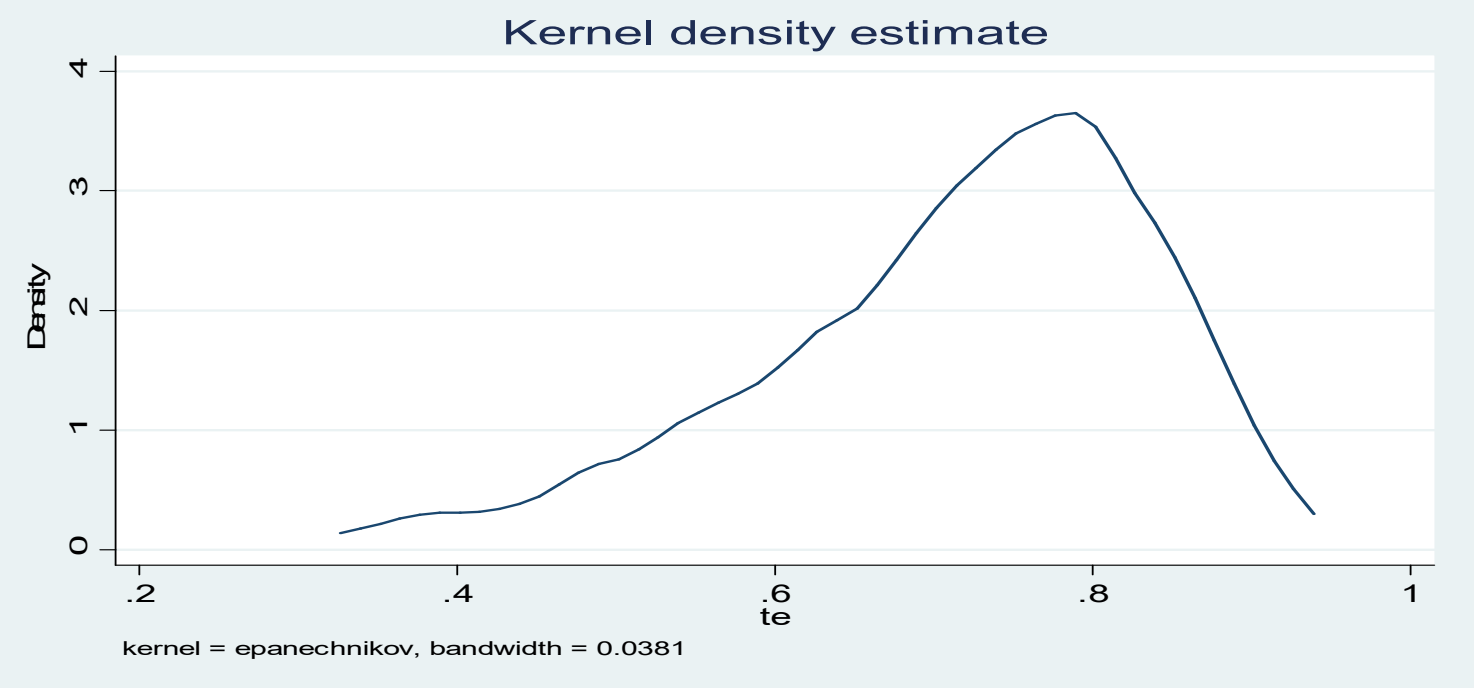

\subsubsection{Source of technical inefficiency of cow milk producers}

Figure 1. Distributions of technical efficiency scores

The technical inefficiency determinants estimated showed age of household, family size, livestock ownership, distance to water, distance to veterinary clinic and distance to milk market was significant in determining inefficiency among the hypothesized determinant variables. Except distance to milk market, all significant coefficients of explanatory variables determined inefficiency with expected direction of influence. The variables significantly determining inefficiency in milk production was significant at $1 \%$ significance level except distance to veterinary clinic, livestock holding and extension contact which are significant at $5 \%, 10 \%$ and $10 \%$ level respectively.

Table 2. Source of technical inefficiency in study area

\begin{tabular}{|l|l|l|}
\hline Variables & Coefficients & Robust Std.Error \\
\hline Age & $-0.14^{* * *}$ & 0.04 \\
\hline Education level & $-0.90^{* * *}$ & 0.24 \\
\hline Family size & $0.70^{* * *}$ & 0.30 \\
\hline Distance to market & -0.036 & 0.07 \\
\hline Distance to veterinary clinic & $0.30^{* *}$ & 0.15 \\
\hline Distance to water for livestock & $0.80^{* * *}$ & 0.17 \\
\hline Farm land size & 0.30 & 0.50 \\
\hline Total livestock holding & $0.2^{*}$ & 0.10 \\
\hline Nom/off farm income & 0.002 & 0.07 \\
\hline Farming system & 2.46 & 1.60 \\
\hline Extension contact & $2.45^{*}$ & 1.42 \\
\hline Dairy training & 1.52 & 2.01 \\
\hline Credit use & 3.50 & 2.30 \\
\hline constant & 2.000 & 3.20 \\
\hline Right censured observation & 1 & \\
\hline Left censured observation & 0 & \\
\hline
\end{tabular}

Codes: significance $0.01 * * * 0.05^{* *} 0.1^{*}$

Age of household: Age of household was proposed to have positive or negative contribution to inefficiency based on the argument that elders households may attach to the existing technology by resisting the new one or were more experienced in production will help to produce more. In this study age of household has significantly contributed to decrease in inefficiency. A year increase in age of a household on an average, holding other factors constant, significantly contributed to decrease in household inefficiency by $0.14 \%$ at $1 \%$ significance level. This showed elder were more technically efficient than younger. Effective pastoral natural resource management is based on a sound knowledge of local user groups of their environment, referred to as pastoralists' indigenous knowledge as stated in Homann (2005). The increase in age of cow producer might help to understand more the environment and existing indigenous knowledge to manage their herd. Selection of cow with important trait characteristics may also took long period of production time. This finding agrees with the work of others including Hassen et al.(2012), Amlaku et al.(2013) Lemma et al.(2013) who found significant contribution of increase in age to technical efficiency in milk production in their studies. 
Family size: As the number of household increase at a fixed technology it is natural that labor productivity will decrease after a certain point in a given activity of production. The areas of pastoralist depend on their fixed technology for a number of periods where the household size thus might fall at diminishing productivity (less efficient use of existing input) with existing technology. This finding showed a unit increase in family size on average, holding other factors constant, contributed to an increase in inefficiency by $0.70 \%$ at $1 \%$ significance level. This finding disagrees with Nakanwagi and Hyuha (2015) and Ajabush (2018) who found increase in family size significantly contributed to technical efficiency of households.

Total livestock holding: It is the total number of livestock owned by a household excluding dairy cows and measured in Tropical Livestock Unit. Livestock ownership was used as proxy variable for wealth of producer and expected to contribute to efficiency of producer's technical efficiency. The result showed opposite as expected and unit increase in tropical livestock unit on average, keeping other determinant variables constant, increase technical inefficiency of producer by $0.2 \%$ at $10 \%$ significance level. Increase in livestock ownership might put producers on wealthy status of those who largely do not depend on milk production for both income and consumption purpose but they may depend on livestock sell. Thus, they might pay less attention for livestock products output management rather than for live animal. This finding disagree with the work of Hassen et al. (2012) who found livestock size contribute to technical efficiency and Adane et al. (2016) who found negative relationship of total household wealth with technical inefficiency during his study.

Extension contact: This variable was dummy variable whether household has contacted with extension agent or not during production period. In this result, apart from expected effects of extension contact on inefficiency, having contact with extension worker, at citrus paribus, contributed to increase inefficiency of household by $2.45 \%$ probability at $10 \%$ significance level. This disagrees with the work of Mosisa (2014) and Ajabush et al. (2018) who found extension contact has significant contribution in reducing technical inefficiency. However in Borana pastoral area, intervention was mainly disregarded the pastoral farming system and extension services favored crop cultivation on valuable grazing areas claiming key resources from the pastoral production (Homman et al.,(2008). Kena et al. (2018) found access to extension has positive contribution in diversifying livelihood strategy of pastoralist that might drive labor for other activities reducing milk production. Other diversification activities might absorbs labor from livestock management activities. This biased intervention might made pastoralist's contact with extension service provider less efficient in milk production.

Education level of household head: Education level of household measured in years of schooling showed negative effect on inefficiency of milk producers. According to this result, an increase in one year of schooling of household contributed to decrease household inefficiency by $0.9 \%$ at $5 \%$ significance level. This results agrees with other works including Mosisa (2014) and Adane et al.(2016) who found positive and significant contribution of education to technical efficiency in milk production.

Distance to veterinary clinic: It is the closeness of the households homestead to the veterinary clinic measured in kilometers. A household relatively nearer to veterinary clinic expected to have less animal health management problem than household far from animal health posts. Animal health care could have an implication to human health as consumption of raw milk is the most preferred diet for producers of the area. As a household's distance to veterinary clinic increase, by one Kilometer on an average citrus paribus, contributed to increase in inefficiency by $0.30 \%$ at $5 \%$ significance level. Household access to health post help households to manage milking cows' health easily, in turn contribute to technical efficiency.

Distance to water point: Water for milking cow requirement is high to produce milk. Thus, as watering is the time consuming activity, the nearer the household to water source the more time saved for watering. Hence, households nearer to water source might be more frequently water their cow compared to household far from water source. Increase in distance of household home from water point in kilometers on an average, holding other factors constant, contributed to increase in inefficient by $0.80 \%$ at $1 \%$ significance level. This finding is consistent with Mosisa (2014) who found distance to water source significantly contributed to inefficiency in milk production.

\section{CONCLUSIONS}

The study aimed to investigate source of technical inefficiency of smallholder cow milk producers in study area. Four assumed inputs variables used in inputs function (Cobb-Douglas) in milk production. This result indicated there still exist to increase milk output by proper use of labor, hay forage and grazing land in study area. The gamma parameter value $(\gamma=0.70)$ shows that variation of actual output from potential output due to inefficiency was accounted to about $70 \%$. As milk production operating below potential with this inputs variables source of such inefficiency investigated for further intervention.

Among variables assumed to be the cause for inefficiency, age of household head, education level of household head were negatively and significantly contributed to decrease inefficiency while size of livestock holding, family size, extension contact, distance to veterinary clinic and distance to water point from respondent's home found to be positively and significant contributed to inefficiency of cow milk producers. 


\section{REFERENCES}

Ajabush Dafar, Belaineh Legesse, Mengistu Ketema (2018). Technical Efficiency in Cow Milk Production: The Case of Babile district of Eastern Hararghe Zone, Oromia National Regional State, Ethiopia. Journal of Economics and Sustainable Development, 9(7):122-128.

Adane Zewdie, Kaleb Shiferaw and Birhanu Gebremedhin. 2016. Sources of technical inefficiency of smallholder farmers in milk production in Ethiopia. African Journal of Agricultural research. 11(19), pp. 1777-1786.

Kebede, A., and Alonso, S. (2018). Improving handling practices and microbiological safety of milk and milk products in Borana pastoral communities, Ethiopia, Feed the Future Innovation Lab for Livestock Systems.

Amlaku, A., Johann, S., and Maria, W. (2013). Innovation and technical efficiency in the smallholder dairy production system in Ethiopia. Journal of Agricultural Science and Technology, 3:151-164.

Azage Tegegne, Berhanu Gebremedhin, Hoekstra, Belay Duguma and Mekasha Yosef. 2013. Smallholder dairy production and marketing systems in Ethiopia: IPMS experiences and opportunities for market-oriented development. IPMS Working Paper 31. ILRI, Nairobi, Kenya.

Berhanu, G., and Hoekstra, B. (2013). Smallholder dairy production and marketing systems in Ethiopia: IPMS Experiences and opportunities for market-oriented development. IPMS (Improving Productivity and Market Success) of Ethiopian farmers project working paper 31. Nairobi: ILRI.

Bekele, M., André, M., Ayana, A., and Anne, V, Z. (2013). The role of livestock diversification in ensuring household food security under a changing climate in Borana, Ethiopi. Journal of springer, Hum Ecology, 42:509-520.

Cossins, NJ,. and Upton, M. 1987. "The Borana Pastoral System of Southern Ethiopia." Agricultural Systems 25: 199-218.

Dejene Takele and Tamiru Amanu (2015). Analysis of marketing and profitability of processing dairy products in the lowland and mid-highland of Borana zone. Global journal of agricultural economics, Extension and rural development 3(7):258-269.

FAO (Food and Agriculture Organization) (2011). Dairy Development Institutions in East Africa: Lessons Learned and Options. Rome, Italy.

FAO (Food and Agriculture Organization) (2013). The Contribution of Livestock to Ethiopian economy. Policy Brief No: ICPALD 5/CLE/8/2013.

Hassen Beshir, Bezabih Emana, Belay Kassa and Jema Haji, 2012. Economic efficiency of mixed crop-livestock production system in the north eastern high lands of Ethiopia: The stochastic frontier approach. Journal of Agricultural Economics and Development, 1(1): 10-20

Homann, S., Rischkowsky, B., and Steinbach, J. 2008. The effect of development interventions on the use of indigenous range management strategies in the Borana lowlands in Ethiopia. Land Degradation Development, 19: $368-387$.

Kena, D., Okoyo Eric and Tefera, T. (2018). Development Livelihood diversification strategies among the Borana pastoral households of Yabello District, Oromia Region, Ethiopia. Journal of Agricultural Extension and Rural (10): 211-221.

Lemma, F., Trivedi, MM., and Patel, AM. (2013). Determinants of technical efficiency of the dairy farmers in Ada'a district of Oromia State, Ethiopia. Iranian Journal of Applied Animal Science 3(1): 59-65.

MoARD (Ministry of Agriculture and Rural Development) (2005). Agricultural Input and Products Marketing Strategy and Implementation Mechanism. MoARD Working Paper, Agricultural Marketing and Inputs Sector, State Ministry, Addis Ababa, Ethiopia.

Mosisa Hirpesa. 2014. Technical efficiency in milk production: The case of Agarfa District, Oromia region, Ethiopia. MSc. Thesis presented to Haramaya University. Haramay, Ethiopia.

Nakanwagi, TT., and Theodora Hyuha (2015). Technical Efficiency of Milk Producers in Cattle Corridor of Uganda: Kiboga District Case. Modern Economy, 6: 846-856. http://dx.doi.org/10.4236/me.2015.67079

Oxfam (2014). Rural Resilience Assessment. Case Study in Borana, Ethiopia. Atkinson Center for a Sustainable Future. Available at:www.acsf.cornell.edu.

Tache Boku and Oba Gufu (2010). "Is Poverty Driving Borana Herders in Southern Ethiopia to Crop Cultivation?" Human Ecology, 38: 639-649 